\title{
Meta-analysis of movements in Atlantic leatherback turtles during the nesting season: conservation implications
}

\author{
Jean-Yves Georges ${ }^{1, *}$, Sabrina Fossette ${ }^{1,2}$, Alexis Billes ${ }^{3}$, Sandra Ferraroli ${ }^{1,2}$, \\ Jacques Fretey ${ }^{4}$, David Grémillet ${ }^{1,5}$, Yvon Le Maho ${ }^{1}$, Andrew E. Myers ${ }^{6}$, \\ Hideji Tanaka ${ }^{7,8,9}$, Graeme C. Hays ${ }^{6}$ \\ ${ }^{1}$ Institut Pluridisciplinaire Hubert Curien-Département Ecologie, Physiologie et Ethologie, Université Louis Pasteur, \\ CNRS-7178, 23 rue Becquerel, 67087 Strasbourg, France \\ ${ }^{2}$ Université Louis Pasteur, 4 rue Blaise Pascal, 67070 Strasbourg, France \\ ${ }^{3}$ Programme Kudu, Cellule de coordination ECOFAC, BP 15115, Batterie IV, Libreville, Gabon \\ ${ }^{4}$ Union Internationale pour la Conservation de la Nature, Museum National d'Histoire Naturelle, \\ 36 rue Geoffroy Saint-Hilaire, 75005 Paris, France \\ ${ }^{5}$ Percy FitzPatrick Institute, University of Cape Town, Rondebosch 7701, South Africa \\ ${ }^{6}$ School of Biological Sciences, Institute of Environmental Sustainability, University of Wales Swansea, Singleton Park, \\ Swansea SA2 8PP, UK \\ ${ }^{7}$ Department of Social Informatics, Graduate School of Informatics, Kyoto University, Yoshida-Honmachi, Sakyo-ku, \\ Kyoto 606-8501, Japan \\ ${ }^{8}$ National Institute of Polar Research, 1-9-10 Kaga, Itabashi-ku, Tokyo 173-8515, Japan \\ ${ }^{9}$ Present address: Graduate School of Fisheries Sciences, Hokkaido University, 3-1-1 Minato-cho, \\ Hakodate 041-8611, Japan
}

\begin{abstract}
Despite decades of conservation efforts on the nesting beaches, the critical status of leatherback turtles shows that their survival predominantly depends on our ability to reduce at-sea mortality. Although areas where leatherbacks meet fisheries have been identified during the long distance movements between 2 consecutive nesting seasons, hot-spots of lethal interactions are still poorly defined within the nesting season, when individuals concentrate close to land. Here we report movements of satellite-tracked gravid leatherback turtles during the nesting season in Western Central Africa, South America and the Caribbean Sea, which account for about $70 \%$ of the world population. We show that during and at the end of the nesting season, leatherback turtles have the propensity to remain over the continental shelf, yet sometimes perform extended movements and may even nest in neighbouring countries. Leatherbacks exploit coastal commercial fishing grounds and face substantial accidental capture by regional coastal fisheries (e.g. at least $10 \%$ in French Guiana). This emphasises the need for regional conservation strategies to be developed at the ocean scale-both at sea and on land - to ensure the survival of the last leatherback turtles.
\end{abstract}

KEY WORDS: At-sea movements · Atlantic Ocean · By-catch · Coastal fisheries · Conservation · Dermochelys coriacea $\cdot$ Endangered species $\cdot$ Leatherback turtle $\cdot$ Nesting season $\cdot$ Site fidelity

\section{INTRODUCTION}

An understanding of how marine animals interact with human activities is urgently needed in order to devise sound management strategies for marine ecosystems threatened by climate change (e.g. Parme- san \& Yohe 2003) and direct anthropogenic pressure (Lewison et al. 2004). Satellite telemetry has provided evidence that long-distance migrating species of commercial interest can perform pan-oceanic movements, regardless of country delimitations (e.g. Lutcavage et al. 1999). Fishing fleets aggregate in areas through 
which such species migrate, thereby increasing the probability of incidental bycatch of species of conservation interest, such as endangered sea turtles (IUCN Red List, available at www.iucnredlist.org), both in oceanic and coastal waters (e.g. Epperly 2003, Ferraroli et al. 2004, James et al. 2005).

While satellite telemetry has been widely used to document the large scale displacements of leatherback sea turtles Dermochelys coriacea between 2 consecutive nesting seasons (e.g. Morreale et al. 1996, Ferraroli et al. 2004, James et al. 2005, Eckert 2006), our knowledge of their movements during the nesting season remains extremely limited. Initially, recovery of flipper tags used on nesting leatherbacks for demographic studies incidentally showed that gravid females can move among regional nesting beaches (e.g. Eckert et al. 1989a, Girondot \& Fretey 1996). Later studies involving radio-telemetry showed that leatherback females from Malaysia, South China and Caribbean disperse 30 to $40 \mathrm{~km}$ from the coastline on the continental shelf, covering up to $300 \mathrm{~km}$ between 2 consecutive nesting events (Chan et al. 1991, Eckert et al. 1989b, 1996). Such telemetry studies sometimes contributed to the establishment of time-area closures and gear modifications that successfully aided the conservation of this species (e.g. Chan et al. 1991, Hays 2004). Yet the precise movements of leatherbacks between 2 consecutive nesting events remain largely unknown in most nesting areas worldwide (but see Eckert et al. 2006, Fossette et al. 2007, this volume).

Interactions of leatherback turtles with coastal fisheries are potentially frequent when females and males congregate close to nesting sites around the nesting season (Chan et al. 1991, James et al. 2005, Fossette et al. 2007) but also in some cases after the nesting season (Eckert et al. 2006). Indeed, accidental catches of sea turtles in coastal and shelf waters have recently been identified as a rapidly emerging threat, particularly for the critically endangered leatherback turtle (FAO 2004). It is therefore crucial not only to know where leatherbacks congregate between 2 consecutive nesting events, but also to detail their at-sea movements during the nesting season. This is necessary in order to gain a better understanding of how leatherbacks interact with fisheries and, ultimately, to assess the magnitude of these interactions.

We examined the movements of satellite-tracked female leatherback turtles during (inter-nesting tracks) and immediately after (post-nesting tracks) the nesting season in Western Central Africa, South America, and the Caribbean Sea, which have accounted for about $70 \%$ of the world population of leatherbacks since their precipitous decline in the Pacific Ocean (Troëng et al. 2004). The 3 study sites have coastal characteristics that range from the wide and narrow continental shelf in South America and Western Africa, respectively, to islands surrounded by deep waters in the Caribbean Sea. Because leatherbacks from South China and the Caribbean have been reported to adjust their at-sea behaviour according to local bathymetry (Chan et al. 1991, Eckert et al. 1989b, 1996), we here aimed to identify general patterns and potential differences in leatherback movements within the nesting season according to coastal specificity at the Atlantic scale. In the Western Atlantic, the immediate proximity of substantial populations nesting in neighbouring countries, and the propensity of this species for straying (i.e. to travel between nesting areas during an inter-nesting interval, Eckert et al. 1989a), suggest that leatherback turtles from this zone may have widespread movements that take them to other countries between 2 consecutive nesting events. We used satellite telemetry to investigate the movements of leatherback turtles between 2 consecutive nesting events in order to gain a better understanding of how potential trans-bordering movements occur, and to identify potential hot-spots where leatherbacks are more likely to interact with fisheries operating in the area.

\section{MATERIALS AND METHODS}

Inter-nesting movements of leatherback turtles were investigated using satellite transmitters (French Guiana and Grenada: Series 9000X satellite relay data loggers, $350 \mathrm{~g}$ in air, $10.5 \mathrm{~cm}$ long, $28 \mathrm{~cm}^{2}$ section, Sea Mammal Research Unit; Gabon 2002: KiwiSat 101 satellite transmitters, $650 \mathrm{~g}$ in air, $18 \mathrm{~cm}$ long, $20 \mathrm{~cm}^{2}$ section, Sirtrack; and Gabon 2003: SDR-T16 satellite transmitters, $380 \mathrm{~g}$ in air, $10 \mathrm{~cm}$ long, $35 \mathrm{~cm}^{2}$ section, Wildlife Computers) and reconstructed using the Argos system (www.argosinc.com). Transmitters were deployed on 9 females nesting at Mayumba Beach on the south coast of Gabon $\left(3.7^{\circ} \mathrm{S}, 10.9^{\circ} \mathrm{E}\right)$ in $2002(\mathrm{n}=5)$ and $2003(\mathrm{n}=4), 13$ females nesting at Levera Beach on the north shore of Grenada $\left(12.2^{\circ} \mathrm{N}, 61.6^{\circ} \mathrm{W}\right)$ in 2002 ( $\mathrm{n}=3$ ) and 2003 ( $\mathrm{n}=10)$, and 10 females nesting at Awala Yalimapo Beach on the western border between French Guiana and Suriname $\left(5.7^{\circ} \mathrm{N}, 53.9^{\circ} \mathrm{W}\right)$ in 2004. At all sites, transmitters were deployed after female turtles had completed their nesting event, and were held on the carapace using a customised flexible harness (S. Fossette et al. unpubl.).

Transmitters were equipped with a salt-water switch that relayed the schedule of time spent in or out of the water. Accordingly, we defined a haul-out as any period >10 min in which the switch was continuously dry. Based on the tracking and haul-out data, along with direct observation in some cases, we inferred 
whether turtles re-nested after transmitter attachment in order to categorise tracks as either inter-nesting or post-nesting tracks, and also to identify potential bycatch of satellite-tracked animals. Movement data were analysed using all Argos-derived positions classified as 1, 2 or 3 (with nominal standard deviations around the true position of 1000,350 , and $150 \mathrm{~m}$, respectively), excluding locations that implied a velocity above $10 \mathrm{~km} \mathrm{~h}^{-1}$ (Fossette et al. 2007). We then calculated the mean daily position for each turtle from the equally weighed latitudes and longitudes obtained for a given day, to provide a simplified representation of movement and to avoid pseudo-replication.

\section{RESULTS}

All 9 turtles from Gabon in 2002 and 2003, all 10 turtles from French Guiana in 2004, and 5 of the 10 turtles tagged in Grenada in 2003 were monitored at sea during at least 1 inter-nesting trip. These turtles spent $10.7 \pm 1.0$ (mean $\pm \mathrm{SD}, \mathrm{n}=9$ complete inter-nesting trips), $10.3 \pm 2.2(\mathrm{n}=8$ complete trips $)$ and $13.8 \pm 3.2 \mathrm{~d}$ ( $\mathrm{n}=5$ complete trips) at sea between 2 consecutive nesting events in Gabon, French Guiana, and Grenada, respectively (Table 1). The leatherbacks moved away from the departure point by only $102 \pm 50 \mathrm{~km}$ off Gabon, $121 \pm 51 \mathrm{~km}$ off French Guiana, and $134 \pm$ $37 \mathrm{~km}$ off Grenada, and yet travelled 100s of $\mathrm{km}$ between 2 consecutive nesting events $(656 \pm 144 \mathrm{~km}$ from Gabon, $560 \pm 134 \mathrm{~km}$ from French Guiana, and $384 \pm 116 \mathrm{~km}$ from Grenada; Table 1). Importantly, leatherback turtles visited waters of neighbouring countries, namely the Republic of the Congo (neighbouring Gabon) (Fig. 1a), Suriname (neighbouring French Guiana) (Fig. 1b), and St. Vincent Island (neighbouring Grenada) (Fig. 1c).

In Gabon, all but 1 (GA06) turtle remained over the shallow continental shelf $(<200 \mathrm{~m}$ depth, Fig. 1a), and 3 turtles (GA04, GA05, GA08) remained in front of the nesting beach within $60 \mathrm{~km}$ of the coast. All other individuals moved parallel to the coast, 2 turtles (GA01, GA09) heading north in Gabonese waters and moving clockwise before returning to the beach. Conversely, the 4 remaining turtles (GA02, GA03, GA06, GA07) headed south to Congolese waters where they moved anticlockwise, with turtle GA06 reaching deep waters ( $>200 \mathrm{~m}$ ) off the Congo. Despite this wide dispersion, turtles spent in total $47 \%$ of their time in shallow waters within $40 \mathrm{~km}$ of Mayumba Beach, and landed $5.0 \pm 2.3 \mathrm{~km}$ (range 1.7 to $9.8 \mathrm{~km}$ ) away from their departure point (Table 1).

Leatherbacks in French Guiana behaved in a similar manner to those in Gabon. All turtles remained over the shallow continental shelf (<200 m depth, Fig. 1b), with 6 individuals reaching waters deeper than $50 \mathrm{~m}$ (FG01, FG02, FG03, FG04, FG05a, FG07a) and the others remaining within $60 \mathrm{~km}$ of Awala-Yalimapo Beach where waters are approx. $20 \mathrm{~m}$ deep. Six individuals (FG03, FG04, FG05, FG06, FG07, FG08) remained in French Guianian waters east of AwalaYalimapo Beach, and moved clockwise before returning to land. Conversely, the 4 remaining turtles headed west into Surinamese waters, where they moved in an anticlockwise direction. Such a pattern, also observed in Gabon, permits returning turtles to remain close to the shore. Turtles spent in total $40 \%$ of their time at sea within an area of $20 \mathrm{~km}$ radius in shallow waters (<50 m depth) in front of the Maroni River estuary (on the border between French Guiana and Suriname), and landed $7.2 \pm 6.0 \mathrm{~km}$ (range 1.8 to $19.8 \mathrm{~km}$ ) away from their departure point (Table 1).

In Grenada, all 5 leatherbacks monitored for their complete inter-nesting trips remained west of the island in deep Caribbean waters, and did not occur over the shallow peri-insular shelf on the Atlantic side, east of Grenada (Fig. 1c). All turtles initially headed north from Levera Beach before moving either clockwise ( $\mathrm{n}=3$ inter-nesting trips) or anticlockwise ( $\mathrm{n}=3$ inter-nesting trips) west of a NE-SW line joining the south coast of St. Vincent to the north coast of Grenada (where Levera Beach lies). All 5 turtles returned to Grenada on Levera Beach or beaches nearby for their subsequent nesting event (Table 1).

The 3 turtles monitored in 2002 and 7 of the 10 turtles studied in 2003 in Grenada were also tracked during the initial phase of their post-nesting movements (Fig. 2). They all remained within the Caribbean Sea for several days before entering the Atlantic Ocean. Most importantly, individual turtles used different routes when entering the Atlantic, passing through almost all channels of the Western Indies Arc. For example, GR12 and GR13 entered the Atlantic by passing between Grenada and St. Vincent, i.e. $100 \mathrm{~km}$ from Levera Beach, whereas GR11 travelled $600 \mathrm{~km}$ within the Caribbean Sea before entering the Atlantic Ocean in the vicinity of St. Croix.

\section{DISCUSSION}

The present tracking study of leatherback turtle movements during the nesting season on both sides of the Atlantic Ocean has identified consistent extended movements between 2 consecutive nesting events, and a wide use of coastal areas ranging from shallow continental shelf and slope waters to deep peri-insular waters throughout this ocean.

The different types of marine habitats used by leatherbacks in Grenada compared with French 
Guiana and Gabon result from contrasting bathymetric and hydrologic conditions between sites. Grenada is a volcanic island characterised by a narrow peri-insular shelf that drops down to $1000 \mathrm{~m}$ within $20 \mathrm{~km}$ of the Atlantic coast, and down to $2000 \mathrm{~m}$ within $10 \mathrm{~km}$ of the Caribbean coast (Fig. 1c). Atlantic surface waters gen- erally flow into the Caribbean between all islands in the Lesser Antilles, and exit via the Yucatan Channel, with surface currents being a great deal faster through the most southern passages (Windward Islands Passages Monitoring Program www.aoml.noaa.gov/phod/ wimp/caribb1.html). Such strong currents may prompt

Table 1. Dermochelys coriacea. Individual summary of inter-nesting movements performed by tracked leatherback turtles nesting in Gabon (GA), French Guiana (FG) and Grenada (GR); a, b, c and d denote successive trips by the same individual. Mean \pm $\mathrm{SD}$ values for each site and for all sites combined were calculated from individual values of turtles monitored over successive trips. ANOVAs were performed to test means among locations

\begin{tabular}{|c|c|c|c|c|c|}
\hline Turtle ID & $\begin{array}{c}\text { Date of } \\
\text { departure }\end{array}$ & $\begin{array}{l}\text { Trip duration } \\
\text { (d) }\end{array}$ & $\begin{array}{l}\text { Total distance } \\
\text { travelled }(\mathrm{km})\end{array}$ & $\begin{array}{l}\text { Max. distance from } \\
\text { tagging location }(\mathrm{km})\end{array}$ & $\begin{array}{l}\text { Distance to second } \\
\text { landing }(\mathrm{km})\end{array}$ \\
\hline GA01 & 19 Dec 02 & 12.2 & 879 & 165 & 3.0 \\
\hline GA02 & 20 Dec 02 & 11.1 & 760 & 163 & 1.9 \\
\hline GA03 & 17 Dec 02 & 10.9 & 446 & 88 & 7.9 \\
\hline GA04 & 24 Dec 02 & 11.9 & 477 & 59 & 3.5 \\
\hline GA05 & 10 Dec 02 & 10.0 & 687 & 34 & 5.3 \\
\hline GA06 & 11 Dec 03 & 10.2 & 742 & 136 & 3.5 \\
\hline GA07 & 11 Dec 03 & 9.3 & 568 & 97 & 7.2 \\
\hline GA08 & 12 Dec 03 & 9.4 & 592 & 45 & 9.8 \\
\hline GA09 & 11 Dec 03 & 11.2 & 756 & 133 & 3.7 \\
\hline FG01 & 15 May 04 & 10.4 & 671 & 189 & 19.8 \\
\hline FG02 & 17 May 04 & 12.2 & 677 & 136 & 2.7 \\
\hline FG03 & 16 May 04 & 10.0 & 578 & 168 & 2.8 \\
\hline FG04 & 16 May 04 & 12.0 & 750 & 191 & 12.3 \\
\hline FG05a & 17 May 04 & 15.0 & 809 & 135 & 2.1 \\
\hline FG05b & 1 Jun 04 & 12.1 & 780 & 53 & 5.7 \\
\hline FG06 & 14 May 04 & 11.4 & 423 & 56 & 1.8 \\
\hline FG07a & 15 May 04 & 11.1 & 699 & 163 & 19.4 \\
\hline FG07b & 26 May 04 & 12.0 & 388 & 35 & 6.7 \\
\hline FG07c & 7 June 04 & 9.9 & 378 & 34 & 6.2 \\
\hline FG07d & 17 June 04 & $-{ }^{\mathrm{A}}$ & $-{ }^{\mathrm{A}}$ & $-{ }^{\mathrm{A}}$ & $-^{\mathrm{A}}$ \\
\hline FG08 & 16 May 04 & 8.7 & 370 & 61 & 3.3 \\
\hline FG09 & 17 May 04 & $5.3^{\mathrm{B}}$ & $394^{\mathrm{B}}$ & $141^{\mathrm{B}}$ & $-{ }^{\mathrm{B}}$ \\
\hline FG10 & 15 May 04 & $9.4^{\mathrm{B}}$ & $579^{\mathrm{B}}$ & $131^{\mathrm{B}}$ & $-{ }^{\mathrm{B}}$ \\
\hline GR01 & 4 Jul 02 & $-{ }^{\mathrm{C}}$ & $-^{\mathrm{C}}$ & $-{ }^{C}$ & $-^{\mathrm{C}}$ \\
\hline GR02 & 7 Jul 02 & $-{ }^{\mathrm{A}}$ & $-{ }^{\mathrm{A}}$ & $-{ }^{\mathrm{A}}$ & $-{ }^{\mathrm{A}}$ \\
\hline GR03 & 9 Jul 02 & $-{ }^{\mathrm{C}}$ & $-^{\mathrm{C}}$ & ${ }_{-}^{\mathrm{C}}$ & ${ }^{\mathrm{C}}$ \\
\hline GR04 & 30 Mar 03 & 18.0 & 343 & 127 & Levera Beach \\
\hline GR05a & 30 Apr 03 & 10.0 & 153 & 65 & Levera Beach \\
\hline GR05b & 11 May 03 & 10.0 & 282 & 114 & Levera Beach \\
\hline GR06 & 5 Apr 03 & 16.0 & 460 & 163 & Levera Beach \\
\hline GR07 & 26 Apr 03 & 12.0 & 378 & 112 & Levera Beach \\
\hline GR08 & 18 May 03 & 13.0 & 520 & 180 & Levera Beach \\
\hline GR09 & 11 May 03 & $-{ }^{\mathrm{C}}$ & $-{ }^{\mathrm{C}}$ & $-{ }^{\mathrm{C}}$ & $-{ }^{\mathrm{C}}$ \\
\hline GR10 & $8 \mathrm{Jul} 03$ & $-^{\mathrm{C}}$ & ${ }^{\mathrm{C}}$ & $-^{\mathrm{C}}$ & ${ }^{\mathrm{C}}$ \\
\hline GR11 & 14 Jun 03 & $-^{\mathrm{C}}$ & $-^{\mathrm{C}}$ & $-^{\mathrm{C}}$ & $-^{\mathrm{C}}$ \\
\hline GR12 & 17 Jun 03 & $-^{\mathrm{C}}$ & ${ }^{\mathrm{C}}$ & $-^{\mathrm{C}}$ & $-^{\mathrm{C}}$ \\
\hline GR13 & 27 Jun 03 & ${ }_{-}^{\mathrm{C}}$ & $-^{\mathrm{C}}$ & $-\mathrm{C}$ & $-^{\mathrm{C}}$ \\
\hline GAall & - & $10.7 \pm 1.0$ & $656 \pm 144$ & $102 \pm 50$ & $5.1 \pm 2.6$ \\
\hline FGall & - & $10.3 \pm 2.2$ & $560 \pm 134$ & $123 \pm 51$ & $7.1 \pm 6.5$ \\
\hline GRall & - & $13.8 \pm 3.2$ & $384 \pm 116$ & $134 \pm 37$ & - \\
\hline ANOVA $(I$ & p-value) & $F_{2,21}=4.959, \mathrm{p}=0.017$ & $F_{2,21}=6.549, \mathrm{p}=0.006$ & $F_{2,19}=0.818, \mathrm{p}=0.455$ & $F_{1,15}=0.715^{\mathrm{D}}, \mathrm{p}=0.411^{\mathrm{D}}$ \\
\hline Pooled dat & & $11.6 \pm 1.6$ & $533 \pm 113$ & $120 \pm 13$ & $6.1 \pm 1.0^{\mathrm{D}}$ \\
\hline \multicolumn{6}{|c|}{${ }^{\mathrm{A}}$ Incomplete record due to accidental catch } \\
\hline \multicolumn{6}{|c|}{${ }^{\mathrm{B}}$ Incomplete record } \\
\hline \multicolumn{6}{|c|}{${ }^{C}$ Post-nesting movement } \\
\hline
\end{tabular}


leatherbacks from Grenada to remain within the deep Caribbean waters rather than enter the Atlantic. Conversely, Gabon and French Guiana have continental shelves that are 50 and $100 \mathrm{~km}$ wide, respectively (Fig. 1a,b), and both are influenced by slower surface currents (Froidefond et al. 2002). Accordingly, leatherbacks can disperse broadly above the continental shelves of Gabon and French Guiana without incur- ring constraints from these weak currents, and their dispersion range at sea is therefore ultimately restricted by the timing of egg-maturation. Our results confirm the results of previous studies that show that leatherbacks adjust their at-sea behaviour according to local bathymetry. For instance, previous studies reported leatherbacks performing deep dives in deep Caribbean waters around St. Croix, US Virgin Islands

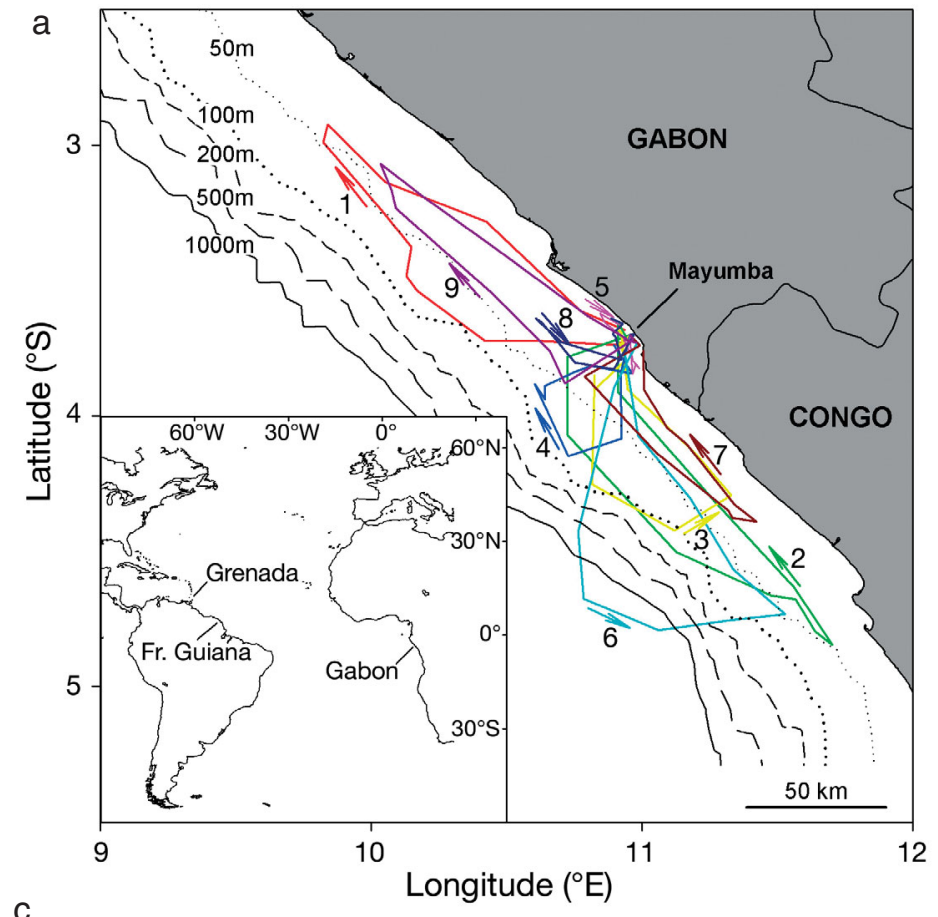

C

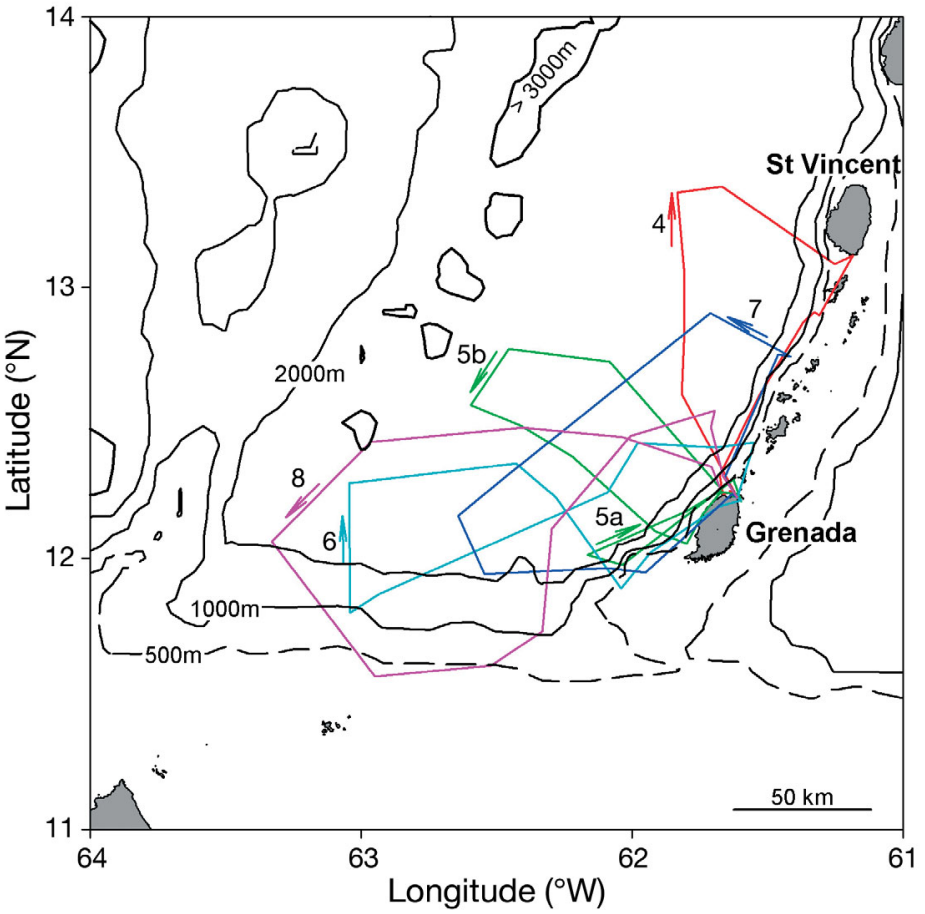

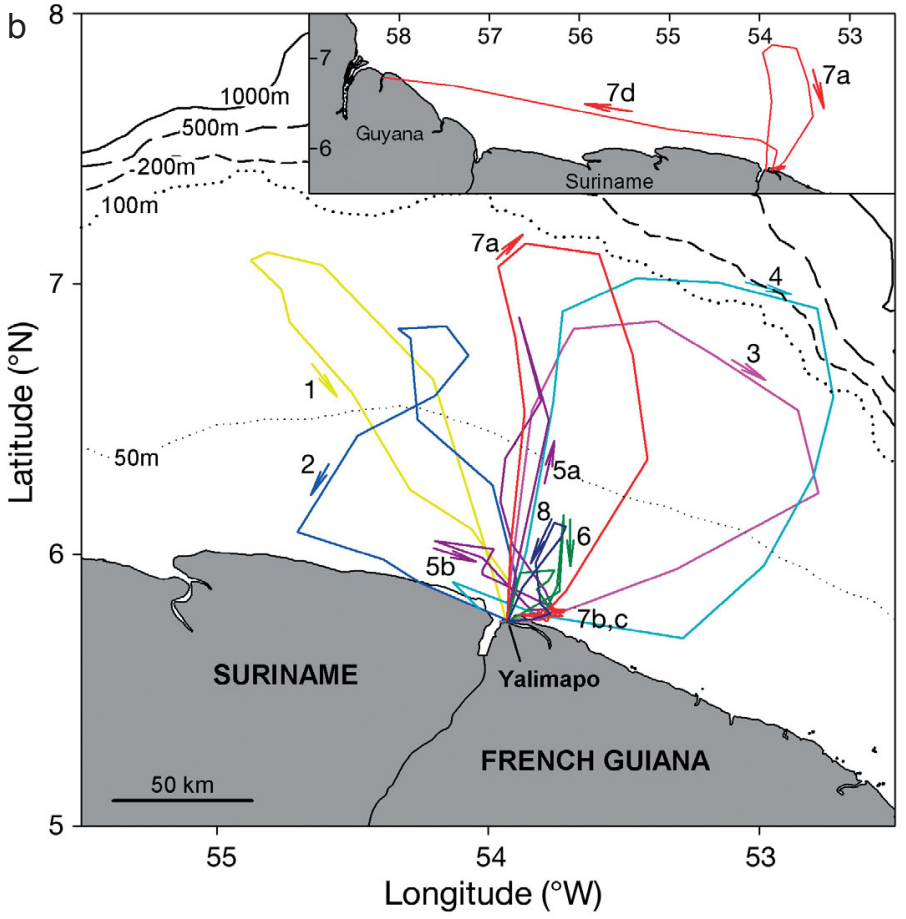

Fig. 1. Dermochelys coriacea. Summary of inter-nesting movements performed by tracked leatherback turtles nesting in (a) Gabon, (b) French Guiana, and (c) Grenada, in relation to bathymetry. Arrows indicate direction of travel with turtle number shown adjacent $(\mathrm{a}, \mathrm{b}, \mathrm{c}$ and $\mathrm{d}$ denote successive internesting tracks by the same individual). (a) Insert: location of 3 study sites; (b) insert: track of the transmitter fitted to FG07, caught during its fourth inter-nesting trip (7d) 


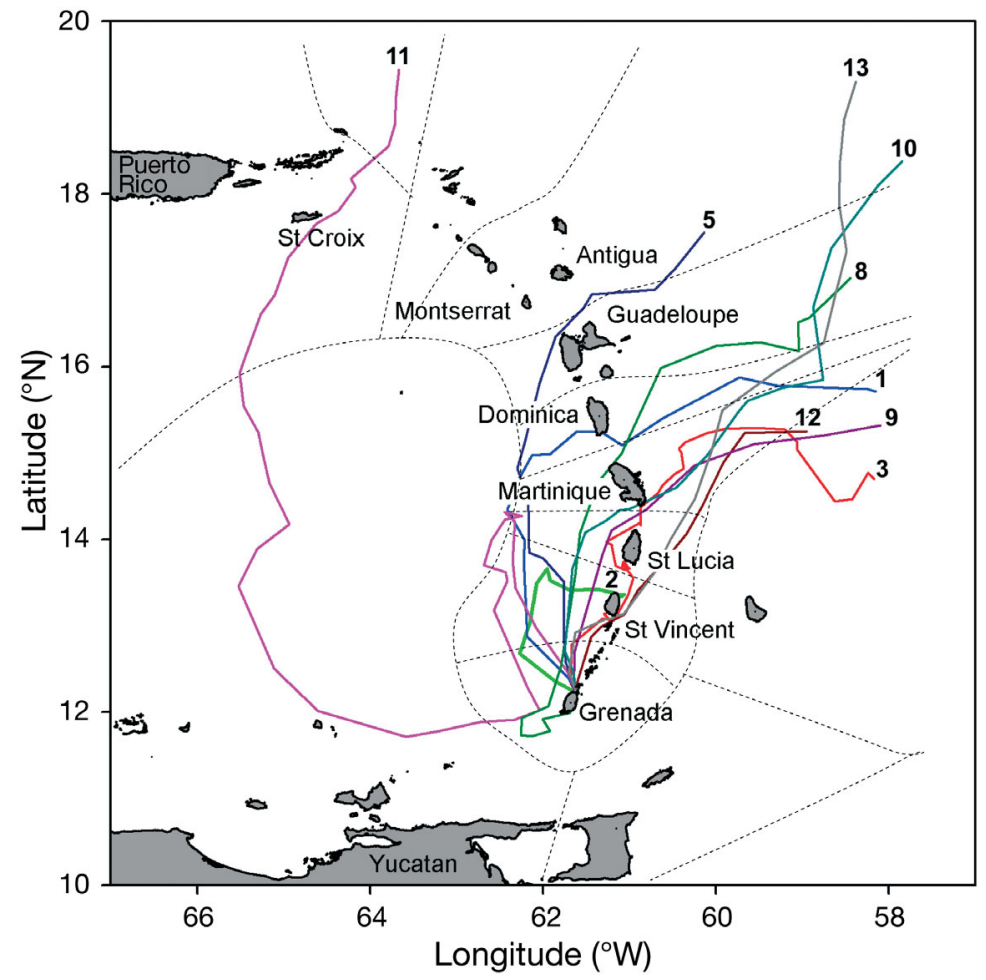

Fig. 2. Dermochelys coriacea. Post-nesting movements of 10 tracked leatherback turtles nesting in Grenada in 2002 and 2003 in relation to Exclusive Economic Zone boundaries in the Caribbean region (dashed lines). The track of turtle GR02 stopped at St. Vincent

(Eckert et al. 1989b), contrasting with their shallow diving behaviour over the shallow continental shelf in South China (Eckert et al. 1996). This indicates that leatherback turtles are primarily deep divers, unless physical constraints such as bathymetry prompt them to restrict their diving performance.

In our study, leatherbacks from Gabon and French Guiana travelled distances that were, on average, 30 to $40 \%$ longer than those travelled by turtles from Grenada. Furthermore, leatherbacks from Gabon and French Guiana travelled these distances in 15 to $20 \%$ less time. Nevertheless, the overall mean dispersion range differed by only 5 to $20 \mathrm{~km}$. Such differences may result from leatherbacks diving to greater depths (Hays et al. 2004) and hence moving shorter horizontal distances in Grenada compared with Gabon and French Guiana, where they mostly move horizontally by performing shallow dives (see Fossette et al. 2007 for French Guiana). The internesting interval durations ranged from 9 to $18 \mathrm{~d}$, as previously reported from tag recaptures (e.g. Girondot \& Fretey 1996). Considering that leatherback turtles lay on average 6 to 7 consecutive nests per season (e.g. Girondot \& Fretey 1996), the inter-nesting movements reported in our study indicate that a leatherback can move between 2000 and $4500 \mathrm{~km}$ during the entire nesting season, depending on the nesting site. Clearly, leatherbacks do not simply rest close to their nesting beach, and the observed extended movements might be associated with mating or foraging. Video data obtained in Costa Rica show that female leatherbacks avoid interactions with males by lying motionless or moving slowly (Reina et al. 2004). The extended movements presented in our study are unlikely to have represented sexual interactions. With regard to foraging, direct and indirect evidence supports the hypothesis that extended movements may be associated with a search for food. Leatherback turtles feed primarily on gelatinous plankton that often forms part of a deep scattering layer in the oceans, moving towards the surface at dusk and descending again at dawn (Davenport 1998). In both French Guiana and the Caribbean Sea, leatherbacks have been reported to dive extensively during the nesting season, exhibiting a diurnal pattern (Eckert et al. 1989b, Hays et al. 2004, Fossette et al. 2007) consistent with feeding within deep scattering layers. Complementary behavioural data, including diving and feeding data, are required (particularly for Gabon) to confirm the hypothesis that leatherback turtles feed during the nesting season.

Our results also reveal interesting consistencies among the study sites, and consequently raise common key conservation issues both at sea and on land for the Atlantic populations of leatherback turtles. During their extensive inter-nesting movements at sea, leatherbacks tend to remain over the continental shelf, when present, but utilise Economic Exclusive Zones (EEZs) from different countries. Most countries maintain these mandatory EEZs up to $200 \mathrm{~km}$ from their shore, within which they control fisheries practices. Four of the 9 leatherback turtles tracked from Gabon visited Congolese waters and moved close to the shore when returning to their nesting site (Fig. 1a). Importantly, illegal trawl-net fisheries are regularly observed from the shore, operating between the coast of Mayumba and the border with the Republic of the Congo (A. Billes, J. Fretey \& J. Georges pers. obs.). Such uncontrolled fisheries may have dramatic impact on sea turtles, including leatherback and also green Chelonia mydas and olive Ridley Lepidochelys olivacea turtles; however, this has never been quantified in Western Africa. In French Guiana, leatherbacks spent $\sim 40 \%$ of their time at sea on the border between 


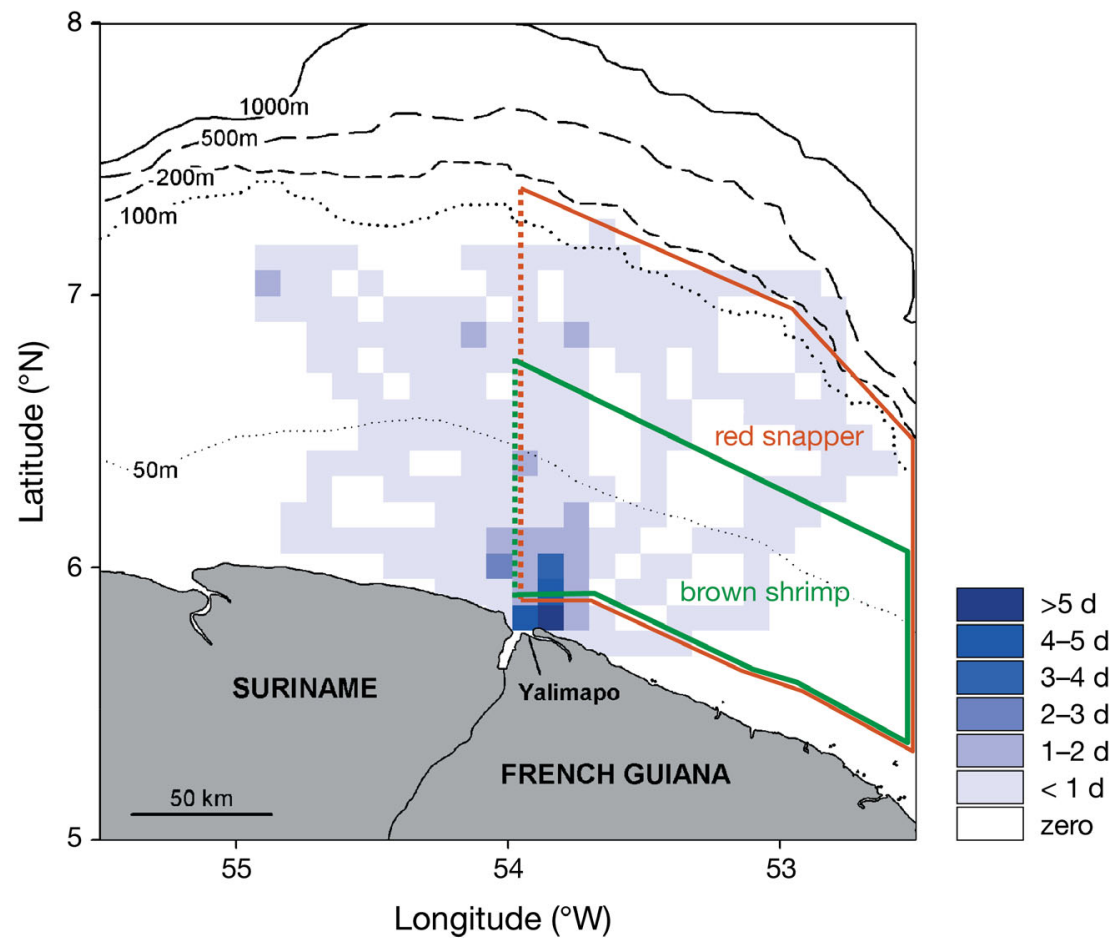

Fig. 3. Dermochelys coriacea. Topographic representation of space use by 10 tracked leatherback turtles during inter-nesting movements off French Guiana, in relation to bathymetry and local fisheries targeting red snapper Lutjanus purpureus (red) and brown shrimp Penaeus subtilis (green). Blue shading denotes total time $(d)$ turtles spent in each $0.1 \times 0.1^{\circ}$ square. NB: fisheries distribution only relates to French Guiana (from Ferraroli et al. 2003)

return information regarding the circumstances of these turtles' captures, nor of their possible release. However, both examples clearly demonstrate that satellite tracking can add valuable information to turtle accidental catch and mortality data, which complement onboard direct observations. Additionally, despite the substantial site fidelity shown here, some individuals from French Guiana routinely visit different beaches and sometimes neighbouring Suriname, probably for nesting.

For some sea turtle populations that remain close to their nesting beach during the breeding season and feed in narrow foraging grounds, focused conservation efforts in restricted areas can prove tremendously successful (e.g. Hays 2004). Our investigation shows that this is clearly not the case for leatherback turtles, which can move far away from nesting beaches during a single inter-nesting interval, frequently crossing international borders and also nesting on the shores of neighbouring countries. A recent study reported that leatherbacks nesting in Florida remain on the Atlantic side of the continental shelf even after

French Guiana and Suriname, with $40 \%$ of turtles moving into Surinamese waters. The coastal area is heavily exploited by 2 main local fisheries that target either brown shrimps Penaeus subtilis or red snappers Lutjanus purpureus (Ferraroli et al. 2003, Fig. 3). These fishing practices occur throughout the nesting season (F. Blanchard pers. comm.) and place leatherback turtles under substantial threat (Ferraroli et al. 2003), as can be seen assessing the data from turtle FG07. After 3 consecutively recorded inter-nesting trips, this turtle was apparently pulled out of the water within French Guiana's EEZ $\left(6^{\circ} \mathrm{N}, 54^{\circ} \mathrm{W}\right)$. Its transmitter then remained within French Guianian waters for a few days before it moved directly to Georgetown, Guyana, at a constant high speed of $13 \mathrm{~km} \mathrm{~h}^{-1}$ over $24 \mathrm{~h}$, indicating that FG07 was captured by a vessel docking in Guyana (Fig. 1b insert). Such data highlight the threats faced by leatherbacks as a result of foreign fisheries operating, sometimes illegally (Ferraroli et al. 2003), in French Guianian waters. Such by-catch may also result from legal local fisheries (Ferraroli et al. 2003). In Grenada, the transmitter attached to turtle GR02 came out of the water and was then located in a village on St. Vincent for several weeks. We did not obtain any the nesting season, yet frequent waters of different states of the USA (Eckert et al. 2006). In the Caribbean Sea, leatherbacks initiate their post-nesting movements by using indirect routes that take them close to many countries. In summary, this study demonstrates that leatherback turtles need to be considered as shared resources not only at sea but also on land. Accordingly, conservation initiatives should be expanded to act on a regional scale (as opposed to national (see e.g. Chan et al. 1991) and beyond (e.g. this study) during the nesting season, in order to assess population trends accurately, define trans-bordering protected areas in both marine and terrestrial terms, and concertedly control international fishing practices so that the survival of the last large population of leatherback turtles can be secured.

Acknowledgements. We are grateful to all concerned public services, particularly the Gabonese Forestry Commission and National Council of the Gabonese National Parks, the Ministry of Ecology and Sustainable Development and Direction Régionale de l'Environnement-Guyane in French Guiana, and the Ministry of Agriculture, Forestry, Land and Fisheries in Grenada. We thank all participants in sea turtle monitoring programmes developed at Mayumba Beach (Nyamu NGO 
and Gabon-Environnement NGO), Awala-Yalimapo Beach (Réserve Naturelle de l'Amana, Kulalasi and T. Doyle) and Levera Beach (Ocean Spirits and J. Houghton) for logistical help in the field. Thanks to F. Blanchard (Institut Français pour la Recherche pour l'Exploitation de la Mer Guyane) for information on fisheries activities in French Guiana. Funding was provided by grants to A.B. and J.F. from the European ECOFAC Program, J.Y.G. and Y.L.M. from the European FEDER Program, and G.C.H. from the Natural Environment Research Council (NERC) of the UK. S.F. and A.E.M. were supported by studentships from the French Ministry of Research and NERC, respectively. This study was conducted within institutional, national and international guidelines, and with authorisations for the use of endangered species in research.

\section{LITERATURE CITED}

Chan EH, Eckert SA, Liew HC, Eckert KL (1991) Locating the internesting habitats of leatherback turtles (Dermochelys coriacea) in Malaysian waters using radio telemetry. In: Uchiyuama A, Amlane CJ (eds) Biotelemetry XI. Proc 11th Int Symp Biotelemetry. Waseda University Press, Tokyo, p 133-138

Davenport J (1998) Sustaining endothermy on a diet of cold jelly: energetics of the leatherback turtles Dermochelys coriacea. Br Herpetol Soc Bull 62:4-8

Eckert SA (2006) High use oceanic areas for Atlantic leatherback sea turtles (Dermochelys coriacea) as identified using satellite telemetred location and dive information. Mar Biol 149:1257-1267

Eckert KL, Eckert SA, Adams TW, Tucker AD (1989a) Internesting migrations by leatherback sea turtles (Dermochelys coriacea) in the West Indies. Herpetologica 45: 190-194

Eckert SA, Eckert KL, Ponganis P, Kooyman GL (1989b) Diving and foraging behavior of leatherback sea turtles (Dermochelys coriacea). Can J Zool 67:2834-2840

Eckert SA, Liew HC, Eckert KL, Chan EH (1996) Shallow water diving by leatherback turtles in the South China Sea. Chelonian Conserv Biol 2:237-243

Eckert SA, Bagley D, Kubis S, Ehrhart L, Johnson C, Stewart K, DeFreese D (2006) Internesting, and postnesting movements and foraging habitats of leatherback sea turtles (Dermochelys coriacea) nesting in Florida. Chelonian Conserv Biol 5:239-248

Epperly SP (2003) Fisheries-related mortality and turtle excluder devices (TEDs). In: Lutz PL, Musick JA, Wyneken J (eds) The biology of sea turtles. CRC Press, Boca Raton, FL, p 339-354

Editorial responsibility: Rory Wilson (Contributing Editor), Swansea, UK
FAO (Food and Agriculture Organisation) (2004) Report of the technical consultation on sea turtles conservation and fisheries. FAO Fish Rep No. 765. FAO, Rome

Ferraroli S, Le Maho Y, Georges JY (2003) Impact de la pêche sur l'environnement et impact de l'environnement sur la pêche: les tortues marines. In: Chapron JY (ed) La surexploitation des ressources marines vivantes. C R Acad Sci, Paris, p 223-229

Ferraroli S, Georges JY, Gaspar P, Le Maho Y (2004) Where leatherback turtles meet fisheries. Nature 429:521-522

Fossette S, Ferraroli S, Tanaka H, Ropert-Condert Y and 5 others (2007) Dispersal and dive patterns in gravid leatherback turtles during the nesting season in French Guiana. Mar Ecol Prog Ser 338:232-247

Froidefond JM, Gardel L, Guiral D, Parra M, Ternon JF (2002) Spectral remote sensing reflectances of coastal waters in French Guiana under the Amazon influence. Remote Sens Environ 80:225-232

Girondot M, Fretey J (1996) Leatherback turtles, Dermochelys coriacea, nesting in French Guiana, 1978-1995. Chelonian Conserv Biol 2:204-208

Hays GC (2004) Good news for sea turtles. Trends Ecol Evol 19:349-351

Hays GC, Isaacs C, King RS, Lloyd C, Lovell P (2004) First records of oceanic dive profiles for leatherback turtles, Dermochelys coriacea, indicate behavioural plasticity associated with long-distance migration. Anim Behav 67: 733-743

James MC, Ottensmeyer CA, Myers RA (2005) Identification of high-use habitat and threats to leatherback sea turtles in northern waters: new directions for conservation. Ecol Lett 8:195-201

Lewison RL, Crowder LB, Read AJ, Freeman SA (2004) Understanding impacts of fisheries bycatch on marine megafauna. Trends Ecol Evol 19:598-604

Lutcavage ME, Brill RW, Skomal GB, Chase BC, Howey PW (1999) Results of pop-up satellite tagging of spawning size class fish in the Gulf of Maine: do North Atlantic bluefin tuna span in the mid-Atlantic? Can J Fish Aquat Sci 56:173-177

Morreale SJ, Standora EA, Spotila JR, Paladino FV (1996) Migration corridor for sea turtles. Nature 384:319-320

Parmesan C, Yohe H (2003) A globally coherent fingerprint of climate change impacts across natural systems. Nature 421:37-42

Reina RD, Abernathy KJ, Marshall GJ, Spotila JR (2004) Respiratory frequency, dive behaviour and social interactions of leatherback turtles Dermochelys coriacea during the inter-nesting interval. J Exp Mar Biol Ecol 316:1-16

Troëng S, Chacón D, Dick B (2004) Possible decline in leatherback turtle Dermochelys coriacea nesting along the coast of Caribbean Central America. Oryx 38:395-403

Submitted: February 22, 2006; Accepted: October 19, 2006 Proofs received from author(s): April 24, 2007 